medRxiv preprint doi: https://doi.org/10.1101/2020.12.12.20247841; this version posted December 15,2020 . The copyright holder for this preprint (which was not certified by peer review) is the author/funder, who has granted medRxiv a license to display the preprint in

It is made available under a CC-BY-NC-ND 4.0 International license .

\title{
Maintenance therapy with infliximab or vedolizumab in inflammatory bowel disease is not associated with increased SARS-CoV-2 seroprevalence: UK experience in the 2020 pandemic
}

Authors: Dr Colleen G C McGregor ${ }^{1}$, Dr Alex Adams ${ }^{1}$, Dr Ross Sadler ${ }^{2}$, Dr Carolina V Arancibia-Cárcamo ${ }^{1}$, Dr Rebecca Palmer ${ }^{1}$, Dr Tim Ambrose ${ }^{1}$, Dr Oliver Brain ${ }^{1}$, Dr Alissa Walsh ${ }^{1}$, Prof. Paul Klenerman ${ }^{1}$, Prof. Simon Travis ${ }^{1}$, Prof. Nicholas M Croft ${ }^{3,4}$, Prof. James O Lindsay ${ }^{3,4}$, and Prof. Jack Satsangi ${ }^{1}$

\section{Institutions:}

1. Translational Gastroenterology Unit, NIHR Oxford Biomedical Research Centre, Oxford University Hospitals NHS Foundation Trust, Oxford, UK

2. Department of Laboratory Immunology, Oxford University Hospitals NHS Foundation Trust, Oxford, UK

3. Centre for Immunobiology, Blizard Institute, Queen Mary University of London, UK

4. Departments of Gastroenterology and Paediatric Gastroenterology, Royal London Hospital, Barts Health NHS Trust, London, UK

\section{Corresponding author contact information:}

Address correspondence to: Dr. Colleen McGregor / Prof. Jack Satsangi

Translational Gastroenterology Unit, Experimental Medicine Division, John Radcliffe Hospital (Level 5), Oxford, OX3 9DU

Email: colleen.mcgregor@ndm.ox.ac.uk / jack.satsangi@ndm.ox.ac.uk

Conflict of interest statement: $\underline{\mathrm{CGCM}}, \underline{\mathrm{AA}}, \underline{\mathrm{TA}}, \underline{\mathrm{RP}}, \underline{\mathrm{OB}}, \underline{\mathrm{PK}}$, and $\underline{\mathrm{JOL}}$ declare no competing interests. $\underline{\mathrm{CVA}-\mathrm{C}}$ has received grants from Celgene and Takeda outside the scope of the submitted work. AW reports personal fees outside the submitted work from Ferring Pharmaceuticals, Janssen, and Takeda. $\underline{\text { ST }}$ reports outside the submitted work receipt of grants/research support from AbbVie, Buhlmann, Celgene, IOIBD, Janssen, Lilly, Pfizer, Takeda, UCB, Vifor, and Norman Collisson Foundation; consulting fees from AbbVie, Allergan, Amgen, Arena, Asahi, Astellas, Biocare, Biogen, Boehringer Ingelheim, Bristol-Myers Squibb, Buhlmann, Celgene, Chemocentryx, Cosmo, Enterome, Ferring, Giuliani SpA, GSK, Genentech, Immunocore, Immunometabolism, Indigo, Janssen, Lexicon, Lilly, Merck, MSD, Neovacs, Novartis, NovoNordisk, NPS Pharmaceuticals, Pfizer, Proximagen, Receptos, Roche, Sensyne, Shire, Sigmoid Pharma, SynDermix, Takeda, Theravance, Tillotts, Topivert, UCB, VHsquared, Vifor, and Zeria; speaker fees from AbbVie, Amgen, Biogen, Ferring, Janssen, Lilly, Pfizer, Shire, and Takeda; no stocks or share options. NMC reports research grants outside the submitted from Abbvie, Shire, Takeda, Pfizer, Eli Lilly, Jansenn, 4D Pharma, and lecture fees Abbvie. $\underline{\mathbf{J}}$ has received lecture fees from Takeda and from the Falk Foundation.

Acknowledgements: The authors wish to acknowledge the contributions to this work by Stephanie Jones, Jennifer Hollis, Bessie Cipriano, Irish Lee, Kinnari Naik, Polychronis Kemos (QMUL), Ruth Ayling (Barts Health NHS Trust), David Eyre, Philippa Matthews, Oxford Radcliffe Biobank, James Chivenga and the TGU Biobank, Oxford Biomedical Research Centre, IBD Specialist Nurses, TGU Investigators*, Department of Clinical Biochemistry (John Radcliffe Hospital), and Clarissa Oeser (Public Health England). The authors also wish to thank Jean-Frederic Colombel and Serre-Yu Wong for helpful and constructive discussion.

* Dr Tim Ambrose, Dr Carolina V Arancibia-Cárcamo, Dr Adam Bailey, Professor Ellie Barnes, Dr Elizabeth Bird-Lieberman, Dr Oliver Brain, Dr Barbara Braden, Dr Jane Collier, Professor James East, Dr Lucy Howarth, Professor Paul Klenerman, Professor Simon Leedham, Dr Rebecca Palmer, Dr Fiona Powrie, Dr Astor Rodrigues, Professor Alison Simmons, Dr Peter Sullivan, Professor Holm Uhlig, Professor Jack Satsangi, Dr Philip Allan, Dr Timothy Ambrose, Dr Jan Bornschein, Dr Jeremy Cobbold, Dr Emma Culver, Dr Michael Pavlides, Dr Alissa Walsh.

Funding: This work was partly funded by the Helmsley Trust as part of the ICARUS study. CGCM is funded

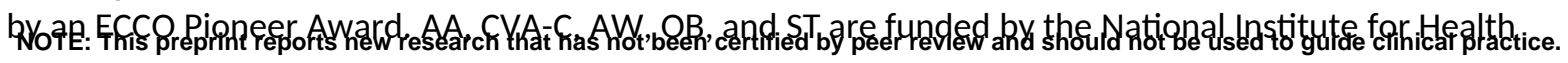


medRxiv preprint doi: https://doi.org/10.1101/2020.12.12.20247841; this version posted December 15, 2020. The copyright holder for this preprint (which was not certified by peer review) is the author/funder, who has granted medRxiv a license to display the preprint in It is made available under a CC-BY-NC-ND 4.0 International license.

Research (NIHR) Oxford Biomedical Research Centre (BRC). The views expressed are those of the authors and not necessarily those of the NHS, the NIHR or the Department of Health.

Ethics: Samples from Oxford patients were collected as a project (ref ORB 20/A054) under the ethical approval of the Oxford Radcliffe Biobank, a research tissue bank that has a favourable opinion from the Oxford C South Central REC, with reference 19/SC/0173. Samples from London patients were collected as a project under the ethical approval of the Digestive Disease Bioresource, Barts Health NHS Trust, a research tissue bank that has a favourable opinion from the Bromley REC, reference 15/LO/2127.

Authors contributions to manuscript: CGCM- patient recruitment, analysis, drafting of manuscript. AAanalysis, drafting of manuscript. RS - sample analysis, manuscript revision. CVA-C, RP, TA, OB, AW, ST, JOL, NMC - patient recruitment, manuscript revision. PK - manuscript revision. JS - initiation of research, recruitment, drafting and revision of manuscript

Data availability: Please contact the corresponding authors for access to anonymised data.

Total word count (excl. tables/references): 1076 
medRxiv preprint doi: https://doi.org/10.1101/2020.12.12.20247841; this version posted December 15, 2020. The copyright holder for this preprint (which was not certified by peer review) is the author/funder, who has granted medRxiv a license to display the preprint in It is made available under a CC-BY-NC-ND 4.0 International license.

\begin{abstract}
Background

There has been great concern amongst clinicians and patients that immunomodulatory treatments for IBD may increase risk of SARS-CoV-2 susceptibility or progression to severe disease.
\end{abstract}

Methods

Sera from 640 patients attending for maintenance infliximab or vedolizumab infusions between April and June 2020 at the John Radcliffe Hospital (Oxford, UK) and Royal London Hospital (London, UK) were tested using the Abbott SARS-CoV-2 IgG assay. Demographic and clinical data were collated from electronic patient records and research databases.

Results

Seropositivity rates of $3.0 \%$ (12/404), 7.2\% (13/180), and $12.5 \%(7 / 56)$ were found in the Oxford and London adult IBD cohorts and London paediatric IBD cohorts respectively. Seroprevalence rates in the Oxford adult IBD cohort were lower than that seen in non-patient facing health-care workers within the same hospital (7.2\%). Seroprevalence rates of the London paediatric IBD cohort were comparable to a contemporary healthy cohort collected at the same hospital (54/396, 13.6\%).

\title{
Conclusions
}

SARS-CoV-2 seropositivity rates are not elevated in patients with IBD receiving maintenance infliximab or vedolizumab infusions. There is no rationale based on these data for elective interruption of maintenance therapy, and we recommend continuation of maintenance therapy. These data do not address the efficacy of vaccination in these patients. 
medRxiv preprint doi: https://doi.org/10.1101/2020.12.12.20247841; this version posted December 15, 2020. The copyright holder for this preprint (which was not certified by peer review) is the author/funder, who has granted medRxiv a license to display the preprint in It is made available under a CC-BY-NC-ND 4.0 International license .

\section{Introduction}

The management of inflammatory bowel disease (IBD) patients treated with biological therapies targeting the immune system has been a key concern throughout the SARS-CoV-2 pandemic. Early guidance from the UK government on self-isolation ("shielding") to patients who were immunocompromised through disease or therapy, was based on expert opinion rather than evidence(1). Elective withdrawal of immunosuppressive therapy was not advised due to the associated risks of IBD relapse.

Evidence is now emerging to clarify this issue, defining the risk of immunomodulatory treatments on SARS-CoV-2 acquisition and disease course(2). Outcomes in patients with IBD who acquire COVID-19 have been reported by the SECURE-IBD registry(3). These data suggest relative safety of anti-cytokine monotherapy and complement seroprevalence data from Germany which reached provocative conclusions suggesting that patients on anti-cytokine therapy might have reduced susceptibility to SARSCoV-2(4). In this study, we analyse the SARS-CoV-2 antibody seroprevalence in patients with IBD receiving systemic anti-TNF therapy (infliximab) or gut-selective immunomodulation with vedolizumab in two UK tertiary IBD centres during the first wave of incidence.

\section{Methods}

Patient recruitment: In total, 640 patients with IBD receiving maintenance infliximab or vedolizumab infusions at the John Radcliffe Hospital (Oxford) and Royal London Hospital, RLH (London) between 20th April - 26th June 2020 were included. Adult (180) and paediatric (56) patients were included from London. Demographic and clinical data were obtained from electronic patient records and IBD databases (Supplementary Table 1). Key differences between the Oxford and London adult cohorts included ethnicity, smoking, comorbidities, disease type, concomitant thiopurines and biologic; in our dataset, London had significantly greater evidence for deprivation than Oxford (Deprivation score 4(3-6.3) vs. 8(69.3), $\mathrm{p}<0.001)$.

SARS-CoV-2 antibody detection: Sera from all patients were tested using the Abbott SARS-CoV-2 IgG assay and Architect i2000SR system, by staff in Oxford. Samples were interpreted as positive according to the manufacturer's cut off value of $\geq 1.4(5)$.

Statistical analyses: Analysis was performed in R (v3.6). Univariable analysis was performed with Fisher's exact test for binary variables, and logistic regression for all other variables. Uncorrected $\mathrm{P}$ values are given. Odds ratios for univariable logistic regression are given with calculated Cls. Seroprevalence data were compared with available data from healthy healthcare workers (HCW) in Oxford(6) and from a PHE seroprevalence study in unselected paediatric patients at RLH.

\section{Results}

No increase in overall SARS-CoV-2 seropositivity in patients with IBD on biologics compared to controls: 12/404(3.0\%) patients tested positive for SARS-CoV-2 antibodies in Oxford. A higher seroprevalence rate was reported from London patients, $13 / 180(7.2 \%)$ for adults $p \leq 0.0001$ and $7 / 56(12.5 \%)$ for children (Table 1). Seroprevalence rates in IBD cohorts were lower than their local healthy controls. Seroprevalence in all Oxford Health Care Workers (HCW, 11.2\%) and in non-patient facing HCW $(7.2 \%)(6)$ were higher $(p<0.0001$ and $p<0.0017$ respectively). Seroprevalence rates of the London paediatric control group were comparable at $13.6 \%$ (54/396, median age 13.0 yrs.(8.1-16.0), male sex $49 \%$ ).

We also analysed clinical and demographic characteristics of the entire cohort in order to identify any associations of SARS-CoV-2 positive patients. There were no associations with baseline characteristics, 
medRxiv preprint doi: https://doi.org/10.1101/2020.12.12.20247841; this version posted December 15, 2020. The copyright holder for this preprint (which was not certified by peer review) is the author/funder, who has granted medRxiv a license to display the preprint in

It is made available under a CC-BY-NC-ND 4.0 International license .

including ethnicity, or deprivation status. In Oxford, a trend toward lower seropositivity was observed in patients on infliximab vs. vedolizumab (1.1\% vs. 4.4\%); only 2 anti-TNF treated patients were seropositive (Table 1). These trends were not observed in adults or children in London. Concomitant budesonide or 5ASA use were associated with higher seropositivity rates, although statistical significance was not reached.

\section{Discussion}

We present the results of the first UK data on SARS-CoV-2 seroprevalence in patients with IBD on biologics at the height of the UK pandemic. We report an overall adult seroprevalence of $3.0 \%$ and $7.2 \%$ in Oxford and London respectively. We also present the first data on a UK paediatric IBD cohort, with a seroprevalence of $12.5 \%$. The differences between centres are consistent with published adult seroprevalence data at the time of our study. The UK Biobank SARS-CoV-2 Serology Study reported a seroprevalence of $6.6 \%$ (5.6-7.6\%) in the South East (Oxfordshire) and 10.4\% (9.6\%-11.2\%) in London. Coupled with our local control data (7.2\%-Oxford, 13.6\%-London (Paediatric)), we demonstrate no increase in seropositivity of patients with IBD on biologics in either centre. Furthermore, when compared to both patient-facing and administrative staff in hospital, seroprevalence rates were lower in IBD.

We observed the lowest rate of seropositivity in Oxford patients with IBD on infliximab. Whilst this was not replicated in the more highly exposed London cohort, it is consistent with the observation and hypothesis of Simon and colleagues(4). The SECURE-IBD data reported, in unadjusted analyses, vedolizumab patients had a higher proportion of severe COVID-19 compared with those on anti-TNFs $(7.2 \%$ vs. $2.2 \%, p=0.007)(2)$. It has been postulated that anti-cytokine therapies may ameliorate or abrogate the 'cytokine storm' associated with severe COVID-19(7).

The seropositivity rates with 5-ASA use in Oxford are also noteworthy in the context of the hypotheses generated by SECURE-IBD data, where 5-ASA use was associated with severe COVID-19 (OR $1.47,95 \% \mathrm{Cl}$ 1.05-2.07)(2). These finding may be artefactual however, reflecting rather the hypothesised potential protective effect of biologics.

Strengths of this study include its deprivation data and two-centre design, with inclusion of both adult and paediatric IBD populations. All samples, including control data, were collected in the same time period and utilised the same assay for analysis. We recognise limitations of our study; including limited power, incomplete exposure history and the presence of confounders with control data comparisons. Whilst the impact of shielding and social distancing practices observed by patients must be considered when interpreting these seroprevalence rates, we consider these findings to be informative, providing evidence to support the continuation of biologics in the COVID-19 era, especially considering the emerging data of deleterious IBD outcomes in those who have discontinued IBD medications during the pandemic(8).

We cannot comment on the durability of response with a single timepoint or whether seropositive patients are protected from re-infection, and therefore we highlight the need for larger, multicentre, prospective, longitudinal studies such as the ICARUS and CLARITY studies, in order to answer the questions of durability and strength of serological response, immunomodulation on SARS-CoV-2 course and risk stratification. These studies also have potential implications in the prioritisation of vaccine delivery in IBD cohorts. 
medRxiv preprint doi: https://doi.org/10.1101/2020.12.12.20247841; this version posted December $15,2020$. The copyright holder for this preprint (which was not certified by peer review) is the author/funder, who has granted medRxiv a license to display the preprint in It is made available under a CC-BY-NC-ND 4.0 International license .

\section{References}

1. Kennedy NA, Jones G-R, Lamb CA, et al. Gut 2020; 69(6):984-90

2. Ungaro RC, et al. Gut 2020; 0:1-8

3. Brenner EJ, Ungaro RC, et al. Gastroenterology 2020;159(2):481-91 e3.

4. Simon D, et al. Nat Commun. 2020;11(1):3774.

5. Public Health England. 2020.

6. Eyre DW, et al. Elife 2020; 9: e60675.

7. Mehta P, et al. Lancet 2020; 395(10229):1033-4.

8. Chen J, et al. Gastroenterology 2020; S0016-5085(20)34779-X

${ }^{*}$ Author names in bold designate shared co-first authorship 
medRxiv preprint doi: https://doi.org/10.1101/2020.12.12.20247841; this version posted December 15,2020 . The copyright holder for this preprint (which was not certified by peer review) is the author/funder, who has granted medRxiv a license to display the preprint in It is made available under a CC-BY-NC-ND 4.0 International license.

Table 1 | 1a. Overall SARS-CoV-2 seroprevalence per cohort. 1b. Seropositivity vs. biologic and IBD diagnoses. 1c. Univariable relationships between clinical, socioeconomic and demographic factors with SARS-CoV-2 seropositivity. All odds ratios for univariable logistic regression are given with calculated $95 \%$ confidence intervals in parentheses. $F=f i s h e r s ~ t e s t$, otherwise logistic regression, all $p$ values uncorrected (Extended analyses Supp. Table 2).

\begin{tabular}{|c|c|c|c|c|}
\hline 1 a. & $\begin{array}{c}\text { Oxford }^{\dagger} \\
n=404\end{array}$ & $\begin{array}{c}\text { London } \\
\mathrm{n}=180\end{array}$ & \multicolumn{2}{|c|}{$\begin{array}{c}\text { London (Paediatric) } \\
n=56\end{array}$} \\
\hline Overall seroprevalence & $3.0 \%(12)$ & $7.2 \%(13)^{* *}$ & \multicolumn{2}{|c|}{$12.5 \%(7)^{a}$} \\
\hline \multirow{4}{*}{$\begin{array}{r}\text { Oxford } \\
\text { IFX }\end{array}$} & CD & UC & IBD-U & Total \\
\hline & 1/105 (1.0\%) & $1 / 66(1.5 \%)$ & $0 / 3(0.0 \%)$ & $\begin{array}{l}2 / 176^{\ddagger} \\
(1.1 \%)\end{array}$ \\
\hline & $4 / 82(4.9 \%)$ & $6 / 144(4.2 \%)$ & $0 / 1(0.0 \%)$ & $\begin{array}{r}10 / 228 \\
(4.4 \%)\end{array}$ \\
\hline & $5 / 187(2.7 \%)$ & $7 / 210(3.3 \%)$ & $0 / 4(0.0 \%)$ & $\begin{array}{l}12 / 404 \\
(3.0 \%)\end{array}$ \\
\hline London & CD & UC & IBD-U & Total \\
\hline IFX & $6 / 85(7.1 \%)$ & $2 / 31(6.5 \%)$ & $0 / 2(0.0 \%)$ & $\begin{array}{l}8 / 118 \\
(6.8 \%)\end{array}$ \\
\hline VDZ & $2 / 21(9.5 \%)$ & $2 / 40(5.0 \%)$ & $1 / 1(100 \%)$ & $\begin{array}{c}6 / 62 \\
(8.1 \%)\end{array}$ \\
\hline Total & $8 / 106(7.5 \%)$ & $4 / 71(5.6 \%)$ & $\begin{array}{c}1 / 3(33.3 \% \\
)\end{array}$ & $\begin{array}{l}13 / 180 \\
(7.2 \%)\end{array}$ \\
\hline \multirow{2}{*}{$\begin{array}{r}\text { London (Paediatric) } \\
\text { IFX }\end{array}$} & CD & UC & IBD-U & Total \\
\hline & $3 / 29(10.3 \%)$ & $3 / 16(18.8 \%)$ & $\begin{array}{c}0 / 3 \\
(0.0 \%)\end{array}$ & $\begin{array}{c}6 / 48 \\
(12.5 \%)\end{array}$ \\
\hline VDZ & $0 / 0(0.0 \%)$ & $1 / 7(4.2 \%)$ & $\begin{array}{c}0 / 1 \\
(0.0 \%)\end{array}$ & $\begin{array}{c}1 / 8 \\
(4.4 \%)\end{array}$ \\
\hline Total & $3 / 29(10.3 \%)$ & $4 / 23(17.4 \%)$ & $\begin{array}{c}0 / 4 \\
(0.0 \%)\end{array}$ & $\begin{array}{c}7 / 56 \\
(12.5 \%)\end{array}$ \\
\hline
\end{tabular}

1c.

Parameter

Age

Sex (Male)

Weight

Deprivation

UC diagnosis

VDZ

5-ASA

Comorbidity
Oxford

OR $(95 \% \mathrm{Cl})$

0.99 (0.96-1.03)

1.80 (0.47-8.32)

1.02 (0.99-1.05)

0.95 (0.75-1.24)

$1.60(0.40-7.58)$

3.98 (0.83-37.85)

3.39 (0.82-12.83)

$0.22(0.01-1.54)$ $\mathrm{p}$ value

0.78

0.39

0.19

0.68

0.55

0.08

0.05

0.19
London

OR $(95 \% \mathrm{Cl})$

1.01 (0.97-1.04)

6.68 (0.95-291.9)

1.00 (0.96-1.03)

1.01 (0.80-1.25)

$0.66(0.14-2.50)$

$1.20(0.30-4.40)$

0.35 (0.01-2.55)

4.59 (1.17-17.44) $p$ value

London (Paediatric)

OR $(95 \% \mathrm{Cl})$ $p$ value

Control data: Seroprevalence in all Oxford HCW 1128/10,034 (11.2\%) and in non-patient facing HCW (administrative staff) 88/1218 (7.2\%) were higher ( $\mathrm{p}<0.0001$ and $\mathrm{p}<0.0017$ respectively) [Chi squared with Yates correction, acknowledging not stratified for confounders]

${ }^{5}$ Control data: Seroprevalence rates of the London paediatric control group were comparable at 54/396 (13.6\%)

*** Oxford vs. London (adult) seroprevalence $P \leq 0.001$

* London adult vs. London paediatric seroprevalence - non-significant

including one 'NA' for diagnoses, "'including two 'NAs' for diagnoses

IFX: Infliximab, VDZ: Vedolizumab, CD: Crohn's disease, UC: Ulcerative colitis, IBD-U: Inflammatory bowel disease-unclassified, 5-ASA: 5-aminosalicylic acid 